\title{
A Pragmatic Study on Jouge Kankei among Japanese Native Speakers: Expressions of Reminder
}

\author{
Sonda Sanjaya, Rosi Rosiah \\ Japanese Language Education Department, Universitas Muhammadiyah Yogyakarta, Yogyakarta, Indonesia \\ sonda.sanjaya@umy.ac.id,rosi.rosiah@umy.ac.id
}

\begin{abstract}
A B S T R A C T
This study aims at investigating the types and categorisation of conversation made by Japanese native speakers. The categorisation of the conversation is made based on vertical relationship (jouge kankei) from the pragmatics perspectives. Descriptive qualitative method is used to conduct the study. The participant of the study includes 14 Japanese native speakers working at Kyoto Minsai Japanese Language School and Palace Side Hotel who took part in role-plays. The results of the study indicate that there is no significant distinction of expressions made by (1) subordinates to their superiors, (2) among colleagues, and (3) from their superiors to their subordinates. These three groups also appear to use similar expressions when talking about promises and requests to borrow books. The distinction was found in expressions made by subordinates to their superiors. In the conversation made among colleagues and by superiors to subordinates, expressions to remind them to return some borrowed books were straightforwardly made. Meanwhile, these straightforward reminders were not found in conversations made by subordinates to their superiors. Additionally, the conversation among colleagues and made by superior to subordinates include expression of emphasizing requests; meanwhile, conversations made by subordinates to superiors do not. In addition, expressions of asking interlocutors' conditions before reminding to return the book are made by colleagues to colleagues and subordinates to superiors and are not made by superiors to subordinates.
\end{abstract}

\section{K E Y W O R D S}

Expressions of Reminder; Japanese Language; Japanese Native Speakers; Jouge Kankei; Pragmatic

\begin{tabular}{lrr} 
A A R T I C L E & I N F O \\
\hline & Final proof accepted: 15 December 2019
\end{tabular}

Available online: 29 December 2019

\section{PENDAHULUAN}

Mengingatkan seseorang pada suatu hal merupakan sebuah perbuatan yang sering dijumpai dalam berbagai aktivitas. Untuk mengingatkan seseorang tentunya diperlukan ungkapan atau ekspresi dan cara agar seseorang yang diingatkan melakukan apa yang seharusnya dilakukan. Kemudian, cara mengingatkan pun tergantung pada budaya, konteks, situasi, kedudukan penutur dan mitra tutur (Sauerland \& Yatsushiro, 2014).

Dalam sebuah situasi misalnya seorang penutur membuat janji bertemu kepada mitra tuturnya. Kemudian, mitra tutur menyediakan waktu untuk menemui namun meminta agar ia diingatkan mengenai waktu agar pertemuan 
dipastikan berlangsung. Konteks seperti itu nampaknya sering dijumpai dalam percakapan sehari-hari di kalangan penutur bahasa Indonesia.

Pada konteks lain tidak jarang juga ketika seorang penutur meminjam sebuah buku, majalah, atau bacaan lainnya kepada mitra tutur, kemudian mitra tutur meminta agar penutur mengingatkannya sehingga bacaan yang diminta dipastikan terbawa. Untuk mengingatkan mitra tutur diperlukan suatu ungkapan atau ekspresi yang tepat agar mitra tutur benar-benar mau membantu sehingga apa yang dibutuhkan penutur dapat dipastikan terpenuhi. Jika ungkapan yang digunakan tidak tepat, dikhawatirkan terjadi kesalahpahaman sehingga dapat menghindari tindakan yang tidak menyenangkan bagi mitra tutur. Tindakan yang tidak menyenangkan dapat juga disebut dengan Face Threatening Act (FTA).

Kesalahpahaman dapat terjadi diakibatkan oleh perbedaan budaya (Haristiani \& Danuwijaya, 2017). Terlebih lagi, gegar budaya (culture shock) seringkali dialami oleh orang yang baru mengenal masyarakat dengan budaya yang baru dikenal (Wijana \& Rohmadi, 2013). Gegar budaya dapat dialami oleh pembelajar bahasa Jepang yang baru mengenal bahasa dan budaya penutur Jepang yang baru memulai komunikasi dengan penutur asli bahasa Jepang. Untuk mengurangi gegar budaya yang disebabkan kesalahpahaman, pembelajar bahasa Jepang perlu memahami cara mengungkapkan suatu ujaran kepada penutur bahasa Jepang dengan ungkapan atau ujaran yang dapat diterima baik oleh penutur bahasa Jepang. Tanpa pemahaman cara mengungkapkan suatu ujaran memungkinkan terjadi hambatan komunikasi.

Dalam konteks mengingatkan, ungkapan dan cara mengungkapkan mengingatkan yang keliru memungkinkan terjadinya kesalahpahaman hingga memburuknya hubungan. Untuk mengurangi kesalahpahaman dan tercapainya tujuan dalam mengingatkan diperlukan sebuah kajian yang menganalisis hingga menemukan macam-macam ungkapan mengingatkan dalam bahasa Jepang. Harapannya, dengan diketahuinya macam-macam ungkapan mengingatkan dalam bahasa Jepang, para pembelajar bahasa Jepang dapat menggunakannya kepada penutur bahasa Jepang dengan harapan apa yang dimaksud dapat diterima dengan baik dan tujuan mengingatkan yang dilakukan dapat tersampaikan kepada penutur bahasa Jepang dengan baik.

Upaya mengingatkan pun bergantung kepada siapa penutur menuturkan ujaran mengingatkan. Berbeda mitra tutur berbeda pula ungkapan yang digunakan penutur untuk menyatakan maksud karena ungkapan sangat dipengaruhi oleh faktor eksternal berupa kedekatan penutur dan mitra tutur, usia, hubungan atas-bawah, gender, dll (Azuma, 2009). Seperti penjelasan di atas, ungkapan dalam bahasa Jepang dipengaruhi oleh hubungan atas-bawah (jouge kankei). Jika mitra tutur memiliki kedudukan yang lebih tinggi daripada penutur, maka ungkapan yang digunakan lebih sopan dan pesan disampaikan dengan eufenisme (enkyoku hyougen). Sedangkan kepada rekan sejawat atau mitra tutur yang kedudukannya lebih rendah daripada penutur, ungkapan cenderung dituturkan secara kasual dan pesan disampaikan secara langsung (straight forward). Dengan demikian, adanya perbedaan kedudukan memungkinkan adanya perbedaan jenis ungkapan yang digunakan untuk mengingatkan sesuatu dalam bahasa Jepang. Ketika berbicara tentang hubungan atas-bawah (jouge kankei) dalam bahasa Jepang tidak akan lepas dari politeness atau kesantunan dalam menggunakan bahasa. Menurut Brown dan Levinson (1987) mengidentifikasi empat strategi kesantunan atau pola perilaku umum yang dapat diaplikasikan penutur yaitu: (1) Bald-on Record Strategy (tanpa strategi), (2) Positive politeness strategy (strategi kesantunan positif/keakraban), (3) Negative politeness strategy (strategi kesantunan negatif/formal), (4) Off-record politeness strategy (strategi tidak langsung atau tersamar). Hal ini mengisyaratkan bahwa pemahaman terhadap strategi kesantunan sangat diperlukan dalam menjaga kelangsungan dan keberhasilan seseorang dalam berkomunikasi (Brown \& Levinson, 1987).

Berdasarkan penjelasan di atas, perlu adanya kajian yang menganalisis pengungkapan mengingatkan dalam bahasa Jepang dengan tinjauan sosiolinguistik dan pragmatik. Kedua bidang tersebut perlu dilibatkan karena saling berkaitan satu sama lain (Wijana \& Rohmadi, 2013). Ditambah lagi, sosiolinguistik berguna untuk memberikan pengetahuan dalam menggunakan bahasa (Chaer \& Agustina, 2014). Dengan demikian, kajian ini dapat memberikan pemahaman khususnya kepada pembelajar bahasa Jepang untuk mengungkapkan ungkapan mengingatkan dalam bahasa Jepang.

Penelitian mengenai ungkapan mengingatkan dalam bahasa Jepang dan bahasa Indonesia sudah dilakukan oleh Sanjaya dan Indraswari (2015). Akan tetapi penelitiannya baru menyentuh perbandingan strategi komunikasi untuk mengingatkan sesuatu dalam bahasa Indonesia dan bahasa Jepang sedangkan jenis atau kategori ungkapannya belum dikaji dalam. Oleh karena itu, perlu adanya penelitian dengan fokus analisis 
macam atau jenis ungkapan mengingatkan dalam bahasa Jepang dengan tinjauan sosiolinguistik dan pragmatik agar para pembelajar bahasa Jepang dapat memahami pengungkapan mengingatkan dalam bahasa Jepang yang sesuai konteks atau situasi percakapan berbahasa Jepang.

Berdasarkan penjelasan di atas, penelitian ini dilakukan dengan tujuan untuk mengetahui jenis atau kategori ungkapan mengingatkan dalam bahasa Jepang dengan tinjauan sosiolinguistik dan pragmatik dengan ruang lingkup percakapan yang dilakukan berdasarkan hubungan atas-bawah (jouge kankei). Hasil penelitian ini akan memberikan kontribusi kepada para pembelajar bahasa Jepang untuk menyusun strategi komunikasi khususnya saat mengingatkan sesuatu kepada penutur bahasa Jepang dalam bahasa Jepang.

\section{METODE PENELITIAN}

Penelitian ini merupakan penelitian deskriptif kualititatif dengan menganalisis, mengklasifikasikan dan mendeskripsikan ungkapan mengingatkan yang dituturkan oleh penutur asli bahasa Jepang. Data penelitian ini diambil dari para partisipan saat bercakap-cakap tanpa partisipasi peneliti sehingga teknik pengambilan yang digunakan adalah teknik simak bebas libat cakap (Zaim, 2014). Data diambil melalui role play yang dilakukan oleh para penutur asli bahasa Jepang sebanyak 14 orang partisipan. Para penutur bahasa Jepang adalah kelompok masyarakat yang tergolong ke dalam shakaijin (masyarakat pekerja) yang bekerja di institusi pendidikan yaitu Kyoto Minsai Language School dan usaha perhotelan yaitu Palace Side Hotel di Kyoto, Jepang.

Roleplay dilakukan dengan pembagian kelompok yang masing-masing kelompok terdiri dari dua orang. Satu orang menjadi peminjam dan yang satu menjadi pemberi pinjaman. Kemudian, kelompok percakapan terdiri dari kelompok percakapan bawahan-atasan, kelompok percakapan antarrekan sejawat (posisi setara), dan kelompok percakapan atasan-bawahan. Kelompok yang berperan sebagai atasan dan bawahan saling bergantian menjadi peminjam dan pemberi pinjaman tanpa mengubah posisi (atasanbawahan) sehingga pada percakapan pertama yang menjadi peminjam adalah atasan sedangkan pada percakapan berikutnya bawahannya yang menjadi peminjam. Begitu juga dengan kelompok yang berperan sebagai rekan sejawat.
Setting percakapan diatur dengan situasi penutur meminjam sebuah buku kemudian mitra tutur menjanjikan akan membawa buku yang diminta pada hari yang ditetapkan. Agar mitra tutur tidak lupa dengan buku yang dijanjikan, penutur mengingatkan pemberi pinjaman sehari sebelum hari yang ditentukan.

Setelah data dari role play terhimpun, peneliti menganalisis data yang berkaitan dengan klasifikasi pengungkapan mengingatkan dalam bahasa Jepang dengan menggunakan model Miles dan Huberman (dalam Sugiyono, 2015) yaitu mengumpulkan, mereduksi, menyajikan data, dan menyimpulkan. Kategorisasi ungkapan mengingatkan dalam bahasa Jepang dianalisis berdasarkan dan model formula semantik Xu (2007).

\section{HASIL DAN PEMBAHASAN}

Seperti pada penjelasan sebelumnya, bahwa penelitian Sanjaya dan Indraswari (2015) baru berfokus pada perbandingan alur percakapan atau strategi yang memunculkan ungkapan mengingatkan dalam percakapan bahasa Indonesia dan bahasa Jepang sedangkan penelitian ini berfokus pada ungkapan mengingatkan penutur bahasa Jepang ditinjau sosiolinguistik dan pragmatik. Dengan demikian, penggunaan ungkapan mengingatkan dalam bahasa Jepang yang sesuai konteks dapat dipahami.

Ungkapan mengingatkan disajikan berdasarkan kedudukan mitra tutur sebagai atasan, rekan sejawat, dan bawahan. Ungkapan tersebut diklasifikasikan dengan formula semantik yang terdiri dari komponen utama, komponen pembantu, dan komponen pengatur wacana.

\section{Ungkapan Mengingatkan kepada Atasan}

\section{Komponen Utama}

Pada dialog yang berlangsung di antara penutur yang berkedudukan sebagai bawahan dan mitra tutur yang berkedudukan sebagai atasan, komponen utama yang ditemukan berupa situasi mitra tutur yang di dalamnya terdapat permintaan informasi atau konfirmasi dan pengingat permohonan. Permintaan informasi atau konfirmasi yang diujarkan penutur (bawahan) kepada mitra tutur (atasan) yang ditemukan 
sebagian besar berupa ungkapan seperti pada contoh (1) s/d (3) berikut ini.

（1）この前お願いした、あのう、本のことなん ですけど。

Kono mae onegai shita, anou, hon no koto nandesukedo.

'Anu, mengenai buku yang saya minta (pinjam) sebelumnya.'

（2）先週お借りしたいと言ってた本があるんで すけれども。

Senshuu okari shitai to itteta hon ga arundesukeredomo.

'Minggu lalu saya bilang ada buku yang ingin saya pinjam.'

（3）先週お願いしてた本を、ええ、借りる約束 なんですけれども。

Senshuu onegai shiteta hon o, ee, kariru yakusokunandesukeredomo.

'Buku yang saya minta (pinjam) minggu lalu, eh, janji pinjam buku itu.'

Kemudian, selain mengonfirmasi, ditemukan ungkapan yang digunakan penutur untuk mengingatkan mitra tutur (atasan) akan permohonan yang diajukan sebelumnya. Ungkapan yang digunakan adalah seperti pada contoh (4).

（4）はい。木曜日持って来るって約束した時、 お願いした。

Hai. Mokuyoubi motte kuru tte yakusoku shita toki, onegai shita.

'Ya, waktu janji akan bawa hari Kamis, saya minta (pinjam).'

\section{Komponen Pembantu}

Komponen pembantu yang ditemukan pada dialog yang berlangsung di antara penutur (bawahan) kepada mitra tutur (atasan) berupa pengurangan syarat yang dinyatakan dengan ungkapan seperti pada contoh (5).

（5）大丈夫ですか。

Daijoubu desuka.

'Tidak apa-apa?'

Adapun komponen pembantu lain yang ditemukan yaitu ungkapan yang dinyatakan penutur untuk mengingatkan hari pemenuhan janji mitra tutur. Ungkapan tersebut dinyatakan pada contoh (6) dan (7) berikut.
（6）今日水曜日ですから、

Kyou mokuyoubi desukara.

'Karena hari ini hari Kamis.'

（7）木曜日までと伺ってたんですけれども。 Mokuyoubi made to ukagattetan desukeredomo. 'Saya dengar Kamis (bukunya dibawa).'

Kalimat (6) merupakan ungkapan yang digunakan untuk mengingatkan mitra tutur dengan cara mengingatkan hari pemenuhan janji mitra tutur secara langsung. Hal ini diketahui karena hari pemenuhan janji mitra tutur adalah hari kamis sedangkan penutur menyatakan bahwa hari ini adalah hari rabu yang berimplikasi bahwa karena hari pemenuhan janji tinggal satu hari lagi. Dengan demikian, penutur secara tidak langsung mengingatkan hari pemenuhan janji adalah besok (Kamis). Sedangkan kalimat (7) mengingatkan hari pemenuhan janji mitra tutur dengan menyebutkan harinya secara langsung dengan ungkapan saya dengar bahwa Kamis akan Anda membawa buku.

\section{Komponen Pengatur Wacana}

Komponen pengatur wacana yang ditemukan dalam dialog antara bawahan dan atasan hanya berupa sahutan. Sahutan yang ditemukan seperti pada contoh (8) dan (9) berikut.

（8）はい。

Hai.

'Ya.'

（9）はい、はい。

Hai, hai.

'Ya, ya.'

Sahutan yang diujarkan hanya berupa kata hai dan hai, hai. Tidak ditemukan sahutan lain dari dialog yang berlangsung di antara semua dialog bawahan dan atasan.Untuk lebih memudahkan pemahaman ungkapan mengingatkan di antara bawahan dan atasan dapat dilihat pada Tabel 1 . 
Tabel 1: Formula Semantik Ungkapan Mengingatkan dalam Dialog Bawahan dan Atasan

\begin{tabular}{|c|c|c|}
\hline $\begin{array}{l}\text { Struktur } \\
\text { Wacana }\end{array}$ & $\begin{array}{c}\text { Jenis dan } \\
\text { Definisi } \\
\text { Formula } \\
\text { Semantik }\end{array}$ & Contoh Kalimat \\
\hline \multirow[t]{2}{*}{$\begin{array}{c}\text { Komponen } \\
\text { utama }\end{array}$} & $\begin{array}{l}\text { Situasi mitra } \\
\text { tutur: meminta } \\
\text { informasi dan } \\
\text { mengonfimasi }\end{array}$ & $\begin{array}{l}- \text { この前お願いし } \\
\text { た、あのう、本の } \\
\text { ことなんですけ } \\
\text { ご。 } \\
\text { - 先週お借りしたい } \\
\text { と言ってた本があ } \\
\text { るんですけれど } \\
\text { も。 } \\
\text { - 先週お願いしてた } \\
\text { 本を、ええ、借り } \\
\text { る約束なんですけ } \\
\text { れども。 }\end{array}$ \\
\hline & $\begin{array}{l}\text { Pengingat } \\
\text { permohonan: } \\
\text { ujaran yang } \\
\text { lazim } \\
\text { digunakan } \\
\text { untuk } \\
\text { mengajukan } \\
\text { permohonan }\end{array}$ & $\begin{array}{l}\text { - はい。木曜日持っ } \\
\text { て来るって約束し } \\
\text { た時、お願いし } \\
\text { た。 }\end{array}$ \\
\hline \multirow[t]{2}{*}{$\begin{array}{l}\text { Komponen } \\
\text { pembantu }\end{array}$} & $\begin{array}{l}\text { Pengurangan } \\
\text { syarat: ujaran } \\
\text { yang } \\
\text { mengurangi } \\
\text { hambatan } \\
\text { permohonan } \\
\text { dengan } \\
\text { memberikan } \\
\text { batasan } \\
\end{array}$ & - 大丈夫ですか。 \\
\hline & $\begin{array}{l}\text { Dll (penguat } \\
\text { ingatan): } \\
\text { ujaran yang } \\
\text { memperkuat } \\
\text { ingatan mitra } \\
\text { tutur }\end{array}$ & $\begin{array}{l}\text { - 今日水曜日ですか } \\
\text { ら、 } \\
\text { - 木曜日までと伺っ } \\
\text { てたんですけれど } \\
\text { も。 }\end{array}$ \\
\hline \multirow{2}{*}{$\begin{array}{c}\text { Komponen } \\
\text { pengatur } \\
\text { wacana }\end{array}$} & $\begin{array}{l}\text { Ujaran berupa } \\
\text { sahutan: } \\
\text { respons berupa } \\
\text { sahutan } \\
\text { terhadap } \\
\text { ujaran } \\
\text { sebelumnya }\end{array}$ & $\begin{array}{l}\text { - はい。 } \\
\text {-はい、はい。 }\end{array}$ \\
\hline & $\begin{array}{l}\text { Pemberian } \\
\text { informasi: } \\
\text { jawaban } \\
\text { terhadap } \\
\text { pertanyaan } \\
\text { mitra tutur }\end{array}$ & $\begin{array}{l}\text { - 今日水曜日です。 } \\
\text { - ノーベル賞の本。 }\end{array}$ \\
\hline
\end{tabular}

\section{Ungkapan Mengingatkan kepada Rekan Sejawat}

\section{Komponen Utama}

Pada dialog yang berlangsung di antara penutur dan mitra tutur yang berkedudukan sama sebagai rekan sejawat, komponen utama yang ditemukan berupa situasi mitra tutur yang di dalamnya terdapat permintaan informasi atau konfirmasi, pengingat permohonan, dan penguat permohonan. Permintaan informasi atau konfirmasi yang diujarkan penutur kepada mitra tutur (rekan sejawat) yang ditemukan sebagian besar berupa ungkapan (10) s/d (17) berikut.

（10）村上先生に、前約束していた、あのう、本 を貸してもらう約束。

Murakami sensei ni, mae yakusoku shiteita, anou, hon o kashite morau yakusoku.

'Oleh Bu Murakami, sebelumnya dijanjikan, anu, janji saya akan dipinjami buku.'

(11)この間お願いしていた。あのう、お借りす るのをお願いした本なんですけれども。

Kono aida onegai shiteita, ano, okari suru no o onegai shita hon nandesu keredomo.

'Beberapa waktu yang lalu saya minta (pinjam), anu, mengenai buku yang saya ingin pinjam.'

(12) 先週あのう、お願いしてた本。 Senshuu anou, onegai shiteta hon. 'Minggu lalu anu, buku yang saya minta (pinjam).'

(13)この間お願いしてた本なんですけど。 Kono aida onegai shiteta hon nandesu kedo. 'Mengenai buku yang saya minta (pinjam) beberapa waktu yang lalu.'

(14) 私、先週頼んでた本。 Watashi, senshuu tanondeta hon. 'Saya, buku yang saya minta (pinjam) minggu lalu.'

(15) ええと、先週は、あのう、本の話し。お茶 の載ってる本についてちょっと楽しくお話 しさせてもらったんですけど。

Eeto, senshuu, wa anou, hon no hanashi. Ocha no notteru hon ni tsuite tanoshiku ohanashi sasete morattandesu kedo.

'Eeh, minggu lalu, eeh, mengenai buku. Saya cerita seru tentang buku yang memuat tentang teh.' 
(16) 田附先生に本を借りるお約束をしましたよ 㸚。

Tazuke Sensei ni hon o kariru yakusoku o shimashita yo ne.

'Bu Tazuke berjanji mengenai saya pinjam buku kepada Ibu, ya.'

(17) 先週に本を貸していただく予定だったんで すけれども。

Senshuu ni hon o kashite itadaku yotei

dattandesu keredomo.

'Minggu lalu (bilang) mengenai saya akan dipinjami buku.'

Kemudian, selain mengonfirmasi, ditemukan ungkapan yang digunakan penutur untuk mengingatkan mitra tutur (rekan sejawat) akan permohonan yang diajukan sebelumnya. Ungkapan yang digunakan seperti pada kalimat (18) s/d (21) berikut.

(18) あのう、覚えてはりますかね。 Anou, oboete harimasuka ne.

'Anu, ingat tidak ya?'

(19) 覚えてません?

Oboetemasen?

'Tidak ingatkah?'

(20) 覚えていらっしやいますか。

Oboete irasshaimasuka.

'Apakah ingat?'

(21) 明日、ベトナム語の本なんですけど。

Ashita, betonamugo no hon nandesu kedo.

'besok (janji buku dibawakan), mengenai buku bahasa Vietnamnya.'

Selain pengingat permohonan, ditemukan pula penguat permohonan yang diujarkan penutur kepada mitra tutur dalam dialog yang berlangsung di antara rekan sejawat (kalimat (22) s/d (24)).

(22) 明日ないと困るので

ashita nai to komaru node.

'Karena kalau besok tidak ada, saya repot.'

(23) ええと、覚えてはります?

Eeto, oboeteharimasu?

'Eeh, apakah ingat?'

(24) あのう、あのう、あの本を授業で使いたい ので。

Anou, anou, ano hon o jugyou de tsukaitai node.

'Anu, anu, buku itu akan saya pakai pada

perkuliahan.'

\section{Komponen Pembantu}

Komponen pembantu yang ditemukan pada dialog yang berlangsung di antara rekan sejawat berupa pengurangan syarat, penguat ingatan, dan dugaan. Pengurangan syarat yang diujarkan penutur kepada mitra tuturnya yang merupakan rekan sejawat yaitu ungkapan (25) berikut.

(25) 大丈夫ですか。

Daijoubu desuka.

'Tidak apa-apa?'

Sedangkan ujaran yang dimunculkan penutur kepada rekan sejawatnya untuk menguatkan ingatan mitra tutur adalah seperti kalimat (26) s/d (30) berikut.

(26) あれ明日なんですけど。 Are ashita nandesu kedo.

'Itu (janji membawa buku) besok.'

（27）文法の本を貸して頂けるとおしゃいました 小。

Bunpou no hon o kashite itadakeruto osshaimashita ne.

'Katanya saya bisa dipinjami buku tata bahasa, ya.'

（28）その時に、もしよかったら、貸してもらえ たらという話があるんですけれども。 Sono toki ni, moshi yokattara, kashite moraetara toiu hanashi ga arundesu keredomo.

'Waktu itu, kalau boleh, katanya saya akan dipinjami (buku).'

（29）貸してもらえたらみたい話で、確かしちゃ ったんですけれども。

Kashite moraetara mitai hanashi de, tashika shicattandesu keredomo.

'Kalau tidak salah, katanya saya mau dipinjami (buku).'

(30) 確か明日持って来てもらうはずだったと思 うんですが。

Tashika ashita motte kite morau hazu data to omoundesu ga.

'Kalau tidak salah besok akan dibawa (bukunya).'

Selain pengurangan persyaratan dan penguat ingatan mitra tutur, ditemukan dugaan yang ditujukan dari penutur kepada mitra tutur. Dugaan yang dimaksud adalah penutur menduga mitra tutur lupa akan permohonan penutur dan pemenuhan janji mitra tutur. Dugaan tersebut diujarkan penutur dengan ungkapan (31) berikut. 
(31) あのう、もしかしてお忘れじやないかなと 思ってて。

Anou, moshikashite owasure janai ka na to omotte te.

'Anu, saya piker barangkali lupa.'

\section{Komponen Pengatur Wacana}

Komponen pengatur wacana yang ditemukan dalam dialog di antara rekan sejawat yaitu berupa permintaan perhatian, sahutan, dan pemberian informasi. Ujaran penutur yang digunakan untuk permintaan perhatian kepada mitra tutur yang merupakan sejawatnya adalah seperti contoh data (32) s/d (36) berikut.

(32) すみません、あのう。

Sumimasen, anou.

"Mohon maaf, anu.'

(33) すみません。

Sumimasen.

'Mohon maaf.'

(34) あっ、そうだ。

$A$, sou da.

'Oh, ya.'

(35) ああ、そうだ。

Aa, sou da.

'Oh, ya.'

(36) えと。

Eto.

'Eeh.'

Kemudian, adapun komponen pengatur wacana berupa sahutan hanya berupa dua ungkapan (37) dan (38).

(37) そうなんです。

Sou nandesu.

'Ya, betul.'

(38) うん。

Un.

'Ya.'

Selain kedua komponen di atas, ditemukan pula komponen pengatur wacana yang menyatakan pemberian informasi. Informasi yang diberikan adalah perihal sesuatu yang dimintai atau dimohonkan sebelumnya oleh penutur kepada mitra tutur. Ungkapan penutur yang digunakan adalah seperti contoh (39) s/d (41) berikut.

(39) 村上春樹の。

Murakami Haruki no.

'Karya Murakami Haruki.'
(40) 木曜日くらい。

Mokuyoubi kurai.

'Kira-kira hari Kamis.'

(41) ええと、能力試験の本です。

Eeto, nouryoku shaken no hon desu.

'Eeh, buku Noryoku Shiken.'

Untuk lebih memudahkan pemahaman ungkapan mengingatkan di antara rekan sejawat dapat dilihat pada Tabel 2 di bawah ini.

Tabel 2: Formula Semantik Ungkapan Mengingatkan dalam Dialog antarrekan Sejawat

\begin{tabular}{|c|c|c|}
\hline $\begin{array}{l}\text { Struktur } \\
\text { Wacana }\end{array}$ & $\begin{array}{l}\text { Jenis dan } \\
\text { Definisi } \\
\text { Formula } \\
\text { Semantik }\end{array}$ & Contoh Kalimat \\
\hline $\begin{array}{l}\text { Komponen } \\
\text { utama }\end{array}$ & $\begin{array}{l}\text { Situasi mitra } \\
\text { tutur: meminta } \\
\text { informasi dan } \\
\text { mengonfimasi }\end{array}$ & $\begin{array}{l}\text { - 村上先生に、前 } \\
\text { 約束していた、 } \\
\text { あのう、本を貸 } \\
\text { してもらう約 } \\
\text { 束。 } \\
\text { - この間お願いし } \\
\text { ていた。あの } \\
\text { う、お借りする } \\
\text { のをお願いした } \\
\text { 本なんですけれ } \\
\text { ども。 } \\
\text { - 先週あのう、お } \\
\text { 願いしてた本。 } \\
\text { - この間お願いし } \\
\text { てた本なんです } \\
\text { けど。 } \\
\text { - 私、先週頼んで } \\
\text { た本。 } \\
\text { - ええと、先週 } \\
\text { は、あのう、本 } \\
\text { の話し。お茶の } \\
\text { 載ってる本につ } \\
\text { いてちょっと楽 }\end{array}$ \\
\hline
\end{tabular}




\begin{tabular}{|c|c|c|}
\hline & & $\begin{array}{c}\text { しくお話しさせ } \\
\text { てもらったんで } \\
\text { すけど。 } \\
\text { - 田附先生に本を } \\
\text { 借りるお約束を } \\
\text { しましたよね。 } \\
\text { - 先週に本を貸し } \\
\text { ていただく予定 } \\
\text { だったんですけ } \\
\text { れども。 }\end{array}$ \\
\hline & $\begin{array}{c}\text { Pengingat } \\
\text { permohonan: } \\
\text { ujaran yang } \\
\text { lazim } \\
\text { digunakan } \\
\text { untuk } \\
\text { mengajukan } \\
\text { permohonan }\end{array}$ & $\begin{array}{c}\text { - あのう、覚えて } \\
\text { はりますかね。 } \\
\text { - 覚えてません? } \\
\text { - 覚えていらっし } \\
\text { やいますか。 } \\
\text { - 明日、ベトナム } \\
\text { 語の本なんです } \\
\text { けど。 }\end{array}$ \\
\hline & $\begin{array}{c}\text { Dll (penguat } \\
\text { permohonan): } \\
\text { ujaran yang } \\
\text { memperkuat } \\
\text { permohonan }\end{array}$ & $\begin{array}{l}\text { - 明日ないと困る } \\
\text { ので } \\
\text { - ええと、覚えて } \\
\text { はります? } \\
\text { - あのう、あの } \\
\text { う、あの本を授 } \\
\text { 業で使いたいの } \\
\text { で。 }\end{array}$ \\
\hline \multirow[t]{2}{*}{$\begin{array}{c}\text { Komponen } \\
\text { pembantu }\end{array}$} & $\begin{array}{l}\text { Pengurangan } \\
\text { syarat: ujaran } \\
\text { yang } \\
\text { mengurangi } \\
\text { hambatan } \\
\text { permohonan } \\
\text { dengan } \\
\text { memberikan } \\
\text { batasan }\end{array}$ & - 大丈夫ですか。 \\
\hline & $\begin{array}{c}\text { D1l (penguat } \\
\text { ingatan): ujaran } \\
\text { yang } \\
\text { memperkuat } \\
\text { ingatan mitra } \\
\text { tutur }\end{array}$ & $\begin{array}{l}\text { - あれ明日なんで } \\
\text { すけど。 }\end{array}$ \\
\hline
\end{tabular}

\begin{tabular}{|c|c|c|}
\hline & & $\begin{array}{c}\text { - 文法の本を貸し } \\
\text { て頂けるとおし } \\
\text { やいましたね。 } \\
\text { - その時に、もし } \\
\text { よかったら、貸 } \\
\text { してもらえたら } \\
\text { という話がある } \\
\text { んですけれど } \\
\text { も。 } \\
\text { - 貸してもらえた } \\
\text { らみたい話で、 } \\
\text { 確かしちやった } \\
\text { んですけれど } \\
\text { も。 }\end{array}$ \\
\hline & $\begin{array}{l}\text { Dll (dugaan): } \\
\text { ujaran yang } \\
\text { menyatakan } \\
\text { dugaan } \\
\text { terhadap mitra } \\
\text { tutur }\end{array}$ & $\begin{array}{l}\text { - あのう、もしか } \\
\text { してお忘れじゃ } \\
\text { ないかなと思っ } \\
\text { てて。 }\end{array}$ \\
\hline \multirow{3}{*}{$\begin{array}{c}\text { Komponen } \\
\text { pengatur } \\
\text { wacana }\end{array}$} & $\begin{array}{l}\text { Permintaan } \\
\text { perhatian: } \\
\text { ujaran yang } \\
\text { bertujuan untuk } \\
\text { menarik } \\
\text { perhatian dari } \\
\text { mitra tutur }\end{array}$ & $\begin{array}{l}\text { - すみません、あ } \\
\text { のう。 } \\
\text { - すみません。 } \\
\text { - あつ、そうだ。 } \\
\text { - ああ、そうだ。 } \\
\text { - えと。 }\end{array}$ \\
\hline & $\begin{array}{l}\text { Ujaran berupa } \\
\text { sahutan: } \\
\text { respons berupa } \\
\text { sahutan } \\
\text { terhadap ujaran } \\
\text { sebelumnya }\end{array}$ & $\begin{array}{l}\text { - そうなんです。 } \\
\text { - うん }\end{array}$ \\
\hline & $\begin{array}{l}\text { Pemberian } \\
\text { informasi: } \\
\text { jawaban } \\
\text { terhadap } \\
\text { pertanyaan } \\
\text { mitra tutur. }\end{array}$ & $\begin{array}{l}\text { - 村上春樹の。 } \\
\text { - 木曜日くらい。 } \\
\text { - ええと、能力試 } \\
\text { 験の本です。 }\end{array}$ \\
\hline
\end{tabular}




\section{Ungkapan Mengingatkan kepada Bawahan}

\section{Komponen Utama}

Pada dialog yang berlangsung antara penutur yang berkedudukan sebagai atasan dan mitra tutur yang berkedudukan sebagai bawahan, komponen utama yang ditemukan berupa situasi mitra tutur yang di dalamnya terdapat permintaan informasi atau konfirmasi, pengingat permohonan, dan penguat permohonan. Permintaan informasi atau konfirmasi yang diujarkan penutur kepada mitra tutur (bawahan) yang ditemukan sebagian besar berupa ungkapan (42) s/d (44) berikut ini.

(42) 大黒先生、あのう、この間お願いしてた、 本なんですけど。

Ooguro Sensei, anou, kono aida onegai shiteta hon nandesu kedo.

'Bu Oguro, anu, buku yang saya minta (pinjam) waktu lalu.'

(43) あのう、借りたいというお約束してました ね。

Anou, karitai to iu yakusoku shitemashita ne.

'Anu, sudah janji kan, saya ingin pinjam buku.'

(44) 石黒さん、本、借りたいゆうてた。

Ishiguro san, hon, karitai yuteta.

'Bu Ishiguro, bilang ingin pinjam buku.'

Kemudian, selain mengonfirmasi, ditemukan ungkapan yang digunakan penutur untuk mengingatkan mitra tutur (bawahan) akan permohonan yang diajukan sebelumnya. Ungkapan yang digunakan hanya satu ungkapan

(45) berikut.

(45) 覚えてる?

\section{Oboeteru?}

'Ingat?'

Selain pengingat permohonan, ditemukan pula penguat permohonan yang diujarkan penutur kepada mitra tutur dalam dialog yang berlangsung di antara rekan sejawat seperti pada contoh (46) dan (47).

（46）明日本当に、本当に明日使わないといけな いので。

Ashita hontou ni, hontou ni tsukawanai to ikenai node.

'Karena besok benar-benar harus saya pakai.'
(47) ちょうど僕は病院で、本を読みたいので。 Choudo boku wa byouin de, hon o yomitai node. 'Karena saat saya di rumah sakit ingin membaca buku.'

\section{Komponen Pembantu}

Komponen pembantu yang ditemukan pada dialog yang berlangsung di antara atasan dan bawahan hanya berupa penguat ingatan. Penguat ingatan yang diujarkan penutur kepada mitra tutur yang merupakan bawahan yaitu ungkapan (48) dan (49) berikut.

(48) 木曜日なんで、今日水曜日やから。 Mokuyoubi nande, kyou suiyoubi yakara

(49) 明日言いましたね。 Ashita iimashita ne. 'Bilang (janjinya) besok, ya.'

\section{Komponen Pengatur Wacana}

Komponen pengatur wacana yang ditemukan dalam dialog di antara atasan dan bawahan yaitu hanya berupa sahutan. Sahutan penutur yang digunakan kepada mitra tutur (bawahan) hanya sahutan seperti contoh (50) berikut.

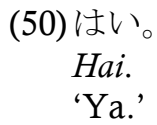

Untuk lebih memudahkan pemahaman ungkapan mengingatkan di antara atasan dan bawahan dapat dilihat pada tabel 3 berikut ini. 
Tabel 3 Formula Semantik Ungkapan Mengingatkan dalam Dialog Atasan dan Bawahan

\begin{tabular}{|c|c|c|}
\hline $\begin{array}{l}\text { Struktur } \\
\text { Wacana }\end{array}$ & $\begin{array}{l}\text { Jenis dan } \\
\text { Definisi } \\
\text { Formula } \\
\text { Semantik }\end{array}$ & Contoh Kalimat \\
\hline \multirow{3}{*}{$\begin{array}{l}\text { Komponen } \\
\text { utama }\end{array}$} & $\begin{array}{l}\text { Situasi mitra } \\
\text { tutur: meminta } \\
\text { informasi dan } \\
\text { mengonfimasi }\end{array}$ & $\begin{array}{l}\text {-大黒先生、あの } \\
\text { う、この間お願 } \\
\text { いしてた、本な } \\
\text { んですけど。 } \\
\text {-あのう、借りた } \\
\text { いというお約束 } \\
\text { してましたね。 } \\
\text {-石黒さん、本、 } \\
\text { 借りたいゆうて } \\
\text { た。 }\end{array}$ \\
\hline & $\begin{array}{l}\text { Pengingat } \\
\text { permohonan: } \\
\text { ujaran yang } \\
\text { lazim } \\
\text { digunakan } \\
\text { untuk } \\
\text { mengajukan } \\
\text { permohonan }\end{array}$ & -覚えてる? \\
\hline & $\begin{array}{l}\text { Dll (penguat } \\
\text { permohonan): } \\
\text { ujaran yang } \\
\text { memperkuat } \\
\text { permohonan }\end{array}$ & $\begin{array}{l}\text { - 明日本当に、本 } \\
\text { 当に明日使わな } \\
\text { いといけないの } \\
\text { で。 } \\
\text {-ちょうど僕は病 } \\
\text { 院で、本を読み } \\
\text { たいので。 }\end{array}$ \\
\hline $\begin{array}{l}\text { Komponen } \\
\text { Pembantu }\end{array}$ & $\begin{array}{l}\text { Dll (penguat } \\
\text { ingatan): } \\
\text { ujaran yang } \\
\text { memperkuat } \\
\text { ingatan mitra } \\
\text { tutur }\end{array}$ & $\begin{array}{l}\text {-木曜日なんで、 } \\
\text { 今日水曜日やか } \\
\text { ら。 } \\
\text {-明日言いました } \\
\text { ね。 }\end{array}$ \\
\hline $\begin{array}{l}\text { Komponen } \\
\text { Pengatur } \\
\text { Wacana }\end{array}$ & $\begin{array}{l}\text { Ujaran berupa } \\
\text { sahutan: } \\
\text { respons berupa } \\
\text { sahutan } \\
\text { terhadap ujaran } \\
\text { sebelumnya }\end{array}$ & -はい \\
\hline
\end{tabular}

\section{SIMPULAN}

Berdasarkan uraian di atas, dapat disimpulkan bahwa ungkapan mengingatkan yang dituturkan oleh bawahan kepada atasan, rekan sejawat kepada rekan sejawat yang lainnya, dan atasan kepada bawahan dilakukan melalui tiga struktur wacana berupa komponen utama, komponen pembantu dan komponen pengatur wacana dengan jenis dan definisi formula semantik yang sama yaitu mengonfirmasi mitra tutur mengenaijanji peminjaman buku dan menguatkan ingatan mitra tutur dengan memunculkan kembali topik buku yang ingin dipinjam penutur atau janji mitra tutur (membawa buku). Perbedaan yang ditemukan yaitu pada bawahan-atasan.Pada percakapan antarrekan sejawat dan percakapan atasan-bawahan ditemukan ujaran pengingat permohonan dengan cara mengonfirmasi secara langsung (straight forward) apakah mitra tutur ingat dengan janjinya atau tidak sedangkan pada percakapan bawahan-atasan tidak ditemukan pengingat permohonan yang diujarkan secara langsung (straight forward) seperti pertanyaan "apakah ingat?" kepada atasannya. Ada kemungkinan bawahan lebih memilih mengonfirmasi ingatan atasan dengan eufenisme (enkyoku) karena kedudukannya yang lebih rendah daripada atasannya. Kemudian, pada percakapan antarrekan sejawat dan percakapan atasanbawahan ditemukan penguat permohonan sedangkan pada percakapan antara bawahanatasan tidak. Ada kemungkinan bawahan cenderung segan untuk lebih memohon atasan untuk membawakan barang yang ingin dipinjamnya.

Dalam hal komponen pembantu, baik pada percakapan bawahan-atasan dan percakapan antarrekan sejawat ditemukan pengurangan syarat dengan menanyakan kondisi mitra tutur seperti daijoubu desuka sedangkan pada percakapan atasan-bawahan tidak ditemukan. Ada kemungkinan pertanyaan tersebut tidak perlu diujarkan kepada bawahan mengingat kedudukan bawahan yang cenderung lebih bersedia memenuhi permohonan atasan. 


\section{REFERENSI}

Azuma, S. (2009). Shakaigengogaku Nyumon. Tokyo: Kenkyusha.

Brown, P., \& Levinson, S. C. (1987). Politeness: Some Universals in Language Usage. Cambridge University Press.

Chaer, A., \& Agustina, L. (2014). Sosiolinguistik Perkenalan Awal. Jakarta: Rineka Cipta.

Haristiani, N. \& Danuwijaya, A. (2017). A Crosscultural Sociopragmatic Study - Apology Speech Act Realization Patterns in Indonesian, Sundanese, and Japanese. The Tenth Conference on Applied Linguistics and The Second English Language Teaching and Technology Conference in collaboration with The First International Conference on Language, Literature, Culture, and Education, Volume 1: CONAPLIN and ICOLLITE, 313-318.

Sanjaya, S., \& Indraswari, T. I. (2015). Analisis Kontrastif Ungkapan Mengingatkan Sesuatu dalam Percakapan Bahasa Indonesia dan Bahasa Jepang: Sebuah Tinjauan Sosiolinguistik. IZUMI, 4(2), 8-15.

Sauerland, U., \& Yatsushiro, K. (2014). Remind-me presuppositions and Speech-Act Decomposition: Japanese kke and German wieder. Ms., ZAS Berlin.

Sugiyono. (2015). Metode Penelitian Pendidikan Pendekatan Kuantitatif, Kualitatif, dan R\&D (21st ed.). Bandung: Alfabeta.

Wijana, I. D. P., \& Rohmadi, M. (2013). Sosiolinguistik Kajian Teori dan Analisis (V). Yogyakarta: Pustaka Pelajar.

Zaim, M. (2014). Metode Penelitian Bahasa: Pendekatan Struktural. Padang: FBS UNP Press.

Xu, M. L. (2007). Irai Kaiwa (Senkoubu) no KousatsuNihongo Bogo Bamen, Taiwanjin Bogo Bamen, Nichi Tai Sesshoku Bamen no Roooru Purei Deeta o Hikaku Shite-, Kotoba to Bunka, 8, 219-238. 